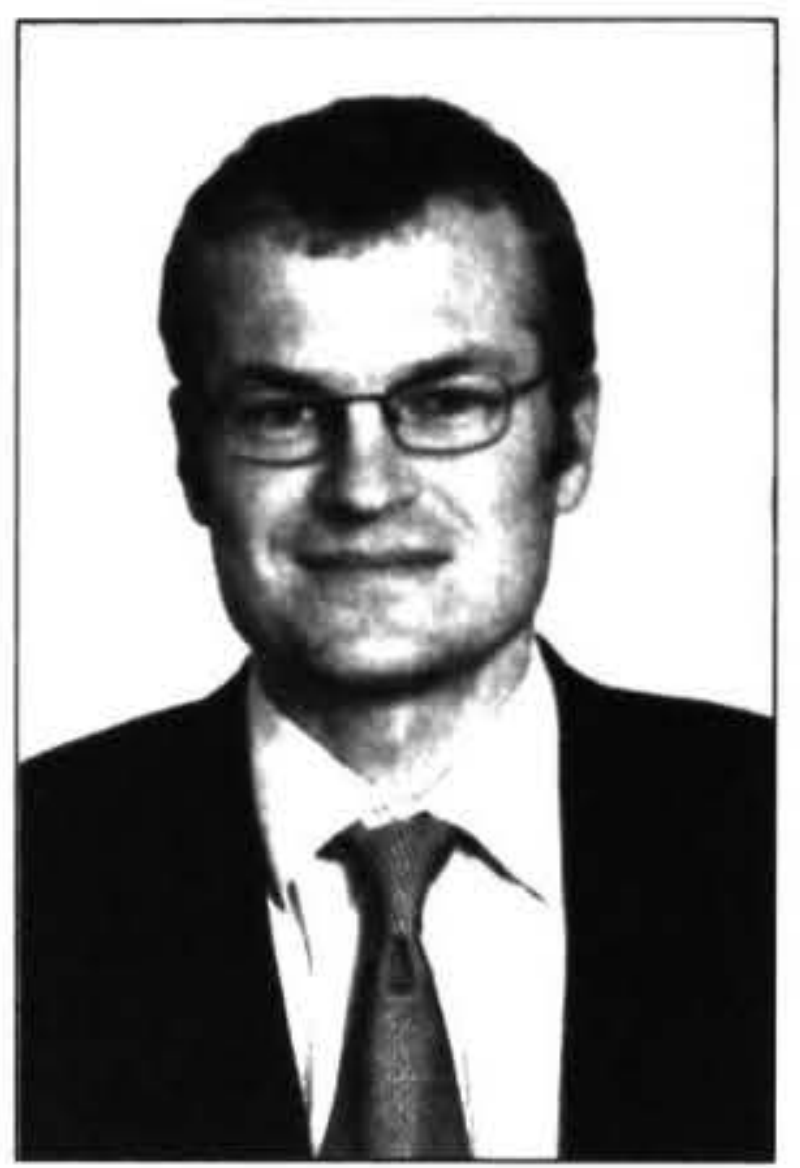

\title{
FROM WORK TO RESIDENCE: \\ AN EVALUATION OF WORK \\ POLICIES THAT PROVIDE A \\ PATHWAY TO PERMANENT \\ RESIDENCE IN NEW ZEALAND'
}

\author{
Paul Merwood \\ Workforce Research and Evaluation, \\ Department of Labour. Wellington
}

\begin{abstract}
In 2002. the Department of Lahour introduced three work to residence' policies, which were designed to help New Zealand emplovers recruit and retain highy skilled and talented migrants. These policies included the Talent Visa (Accredited Employers). Talent V'isa (Arts. Culture and Sports), and the Long Term Skill Shortage List Occupation work permit. This paper describes the characteristics of migrants approved through the work to residence policies, the characteristics of accredited employers and the migrants ther employ: and the transition patterns from temporary to permanent residence. The research involved a quantitative analysis of administrative data, an online survey of accredited employers, and qualitative interviews with policy stakeholders.
\end{abstract}

The research showed that orer 4.000 migrants had heen granted a work permit through these policies, and almost one third had made the transition to permanent residence. Migrants hrought to New Zealand a diverse range of skills, and of those migrants approved for permanent residence, most did so through a skilled residence category. It was found that the Talent Iisa (Accredited Employers) policy enahled employers to expedite the recruitment of overseas workers. and the rork to residence aspect was an attractive incentive for potential migrants.

\section{Introduction}

In 2001, the Department of Labour (DoL) undertook a review of temporary work policy. A key outcome from this review was Cabinet's agreement to an overarching work policy objective. which was to complement residence policy by contributing to developing New Zealand's capacity base.

The review of temporary work policy proposed the introduction of a Talent Visa, in essence a temporary work policy that would facilitate the transition from skilled worker to permanent resident. Talent Visa policy would position work policy as opportunity driven', enabling employers to select talented, skilled migrants most likely to benefit New Zealand without having to first establish that a vacancy exists. The link to permanent residence was intended to help New Zealand retain these highly skilled and talented migrants.

In April 2002, three new work to residence policies came into effect. These included the Talent (Accredited Employers), Talent (Arts. Culture and Sports), and the Priority Occupations List (now known as the Long Term Skill Shortage List Occupation policy, or LTSSL). Applicants through these three work permit categories are issued a multiple entry work visa or permit allowing a stay in New Zealand of 30 months, and become eligible for permanent residence after two years if they meet the requirements of the associated residence policy.

\section{Work to Residence Policies}

The Talent (Accredited Employers) policy allows accredited employers to supplement their workforce through the recruitment of non-New Zealand workers whose talents are required by the employer. Accredited employers must have direct responsibility for the migrants they employ and their work output.

An employer must meet certain criteria to become accredited, which include being in a sound financial position and having a high standard of human resource policies and processes, good workplace practices, a commitment to training New Zealanders, and a record of compliance with immigration and employment legislation.

Employers are granted accreditation for 12 months, after which time they must make an application for renewal annually. To qualify for a work permit through the Talent (Accredited Employers) policy, an applicant must have an offer of employment with an accredited employer. The job offer must be for at least two years, be full-time, and have a minimum base salary of $\$ 45,000$. Applicants must be no older than 55 and must meet health and character requirements.

The Talent (Arts, Culture and Sports) policy enables major New Zealand cultural and sporting organisations to sponsor 
talented individuals who have an exceptional record of achievement and are still active in their chosen field. Organisations need to give reasons that the applicant's presence in New Zealand would enhance the qualities of New Zealand's accomplishments by their participation in a given field of art, sport, or culture.

Applicants through the Talent (Arts, Culture and Sports) work policy must have exceptional talent in a declared field of art, culture, or sport. Sponsoring organisations are required to undertake an initial twoyear commitment of support, accommodation and, if required, repatriation. Applicants must be no older than 55 and meet health and character requirements.

Under LTSSL Occupation policy, applicants must have an offer of employment in an occupation on the Long Term Skill Shortage List, and must meet the specifications for the occupation. The job offer must be for at least two years, be full-time, and applicants must be suitably qualified by training and/or experience to undertake the offer of employment (including any specific requirements set out on the Long Term Skill Shortage List). There is no specific age limit or salary threshold for people applying through LTSSL Occupation work permit policy."

Three residence policies complement the Talent Visa and LTSSL Occupation work permit policies. Talent Visa and LTSSL Occupation work permit holders may be granted residence through the associated residence policies after holding their work permit for 24 months. Applicants must have met the employment conditions of their work permit for the 24-month period.

Talent (Accredited Employers) and LTSSL Occupation residence applicants must have full-time employment with a minimum base salary (calculated on the basis of a 40 -hour week) of $\$ 45,000$. $^{3}$ Applicants through the LTSSL Occupation residence policy must be no older than 55. Since April 2004, applicants for residence through the Talent Visa and LTSSL Occupation residence categories must be in New Zealand at the time they lodge their application.

\section{Purpose of Research and Methodology}

The objective of this research was to describe the characteristics of accredited employers and the migrants they employ, the accreditation process, and trends in Talent Visa and LTSSL Occupation applications since the policies came into effect. The research also identified the strengths and limitations of Talent (Accredited Employers) policy.

The research involved a quantitative analysis of the Department of Labour's Immigration database, and an analysis of the feedback sought from key stakeholders. ${ }^{4}$ An online survey was conducted with accredited employers, and qualitative interviews were undertaken with immigration advisers and immigration officers at the Business Migration Branch in Wellington. The online survey of accredited employers was conducted in May 2006. Responses were received from 71 out of 135 employers sent an email, giving a 53 percent response rate.

The data used in this research had a number of limitations. In some analyses, the administrative data used was not complete. For example, variables such as region, occupation, or salary, were not recorded for every permit application, or were recorded in a way that was unusable. Furthermore, 13 percent of Talent (Accredited Employers) work permit holders could not be matched to an accredited employer because employer contact details were not recorded against the work permit application. The online survey was limited to those for whom a valid email address was held. In this regard, small and medium-sized employers were not well represented in the survey response data.

\section{Discussion of Main Findings}

\section{Accredited Employers and the Migrants They Employ}

Between April 2002 and October 2005, 565 employers were accredited and approximately 61 percent have maintained their accreditation status over time. Accredited employers represented a broad range of industries, they tended to be larger than the average New Zealand business, well established, and many were based in Auckland ( 61 percent).

Sixty applications for accreditation were declined between April 2002 and October 2005. This equates to 9.6 percent of the 625 applications. A further 14 applications for renewal, out of 466 applications, were declined. Decline rates were highest for the small employers and those with relatively few years in business. Of the 56 (out of 60 ) declined applications with employer size recorded, 70 percent were made by employers with fewer than 20 employees. Of the 60 declined employers (of whom 57 recorded their number of years in business), 79 percent had been in business for less than 10 years.

The largest accredited employers employed the majority of work permit holders approved through the Talent (Accredited Employers) policy. Small employers (fewer than 20 employees) accounted for 21 percent of accreditations but employed only 6 percent of Talent (Accredited Employers) work permit holders. Overall, most accredited employers employed fewer than six Talent (Accredited Employers) work permit holders.

Employers were asked to rate their ability to recruit skilled New Zealanders and skilled migrants (non-New Zealand residents either already in New Zealand or offshore) in recent years. Forty-five percent of respondents rated their ability to employ skilled New Zealanders as good or very good, while 76 percent rated their ability to recruit migrants as good or very good. Employers were asked to estimate the length of time migrants they employed had remained in their employ. Of those employers with current employees on Talent Visa work permits, 80 percent reported that the migrants had been working for them for one year or more. While some migrants had left the employers' business within 2 years, almost half ( 47 percent) reported that the migrants they employed were still working for them. 
Table 1: Work permit holders by employer size.*

\begin{tabular}{lcc}
\hline \multirow{2}{*}{$\begin{array}{l}\text { Employer } \\
\text { size }\end{array}$} & \multicolumn{2}{c}{ Number of work permit holders } \\
\cline { 2 - 3 } & $\mathbf{n}$ & $\boldsymbol{\%}$ \\
\hline $1-5$ & 28 & $1 \%$ \\
$6-9$ & 44 & $2 \%$ \\
$10-19$ & 68 & $3 \%$ \\
$20-49$ & 218 & $10 \%$ \\
$50-99$ & 145 & $7 \%$ \\
$100+$ & 1,663 & $77 \%$ \\
\hline Total & $\mathbf{2 , 1 6 6}$ & $\mathbf{1 0 0 \%}$ \\
\hline
\end{tabular}

Data was not available for $13^{\circ}$ of Talent (Accredited Employers) work permit holders.

An analysis of interview responses showed that many stakeholders valued the speed that work permits could be processed. the ease of the process, and how these factors amounted to an efficient, streamlined recruitment process. When asked about the advantages of being accredited, over half of the employers described the speed of processing and the certainty this gave applicants.

The high degree of customer service received from the Department of Labour's Business Relationship Advisers also came through strongly in employers" responses to the online survey. Having a nominated point of contact in the Business Migration Branch was important for some employers.

Conversely, a number of employers criticised immigration staff on their lack of understanding of Talent Visa policy, particularly in relation io the prioritisation of work permit applications. This criticism was confined to employers who had dealt with branches other than the Business Migration Branch.

Many employers felt that being aceredited had enabled them to recruit the people they needed, and some felt that without the Talent Visa policy they would have had difficulty finding staff. Employers also felt that the path to residence gave migrants more certainty and this amounted to a better recruiting ability of employers.

The interviews with immigration advisers also reinforeed that the path to residence provided security to migrants, and this was a good selling point for employers:

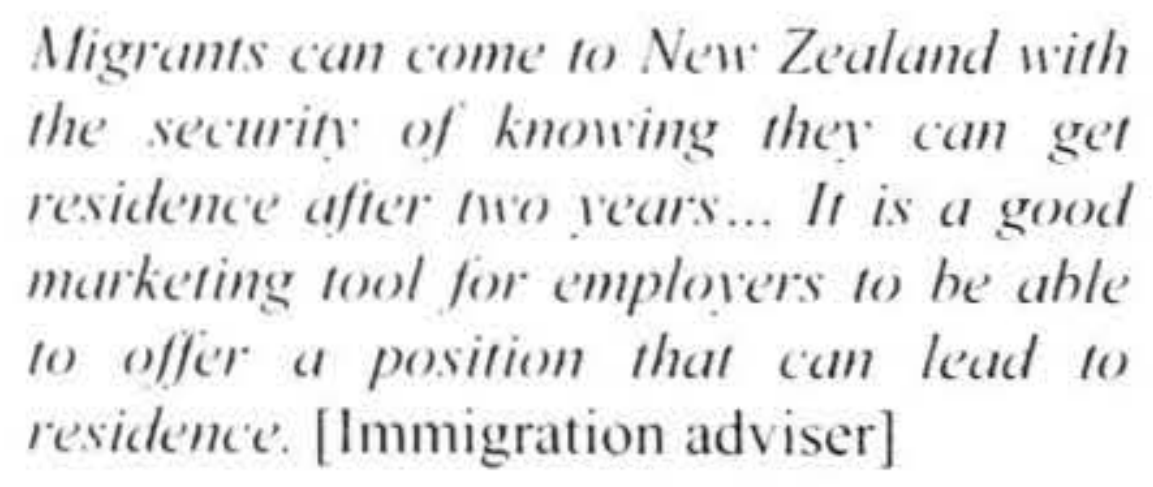

Overall, the interviews with key stakeholders and the survey of employers identified relatively few shortcomings in the policy. Many employers who responded to the online survey stated that they had found no disadvantages with the Talent Visa policy. Of those who had experienced shortcomings in the policy, some were related to the salary threshold and the way it is calculated. Some stakeholders reported that the salary threshold was too high and limited an employer's ability to recruit. Others reported that the salary threshold was too low, and no longer restricted the policy to highly skilled people.

A combination of administrative data and survey data showed that the salaries paid to Talent (Accredited Employers) work permit holders tended to be well in excess of the policy threshold of $\$ 45,000$ per annum. However, there were significant differences between occupational groups. On average, the salaries paid to work permit holders in Service and sales, Agriculture and fishery, Trades, and Plant and machine operators tended to be nearer the $\$ 45,000$ threshold than other occupational groups.

Some stakeholders felt that the Skilled Migrant Category (SMC) had undermined Talent Visa policy, because many people who could qualify through Talent Visa policy could also qualify for residence through the SMC. The ease of which Talent (Accredited Employers) work permit holders could 'category jump' was felt by some to undermine an employers' ability to retain staff employed through the policy."

\section{Talent l'isa and LTSSL Work Permit Holders}

Between April 2002 and October 2005, 4,064 people were approved through the three work to residence policies. Sixty-one percent ( 2.487 people) were approved through the Talent (Accredited Employers) policy, 35 percent $(1,427$ people) through the LTSSL Occupation policy, and the remaining 4 percent ( 150 people) through the Talent (Arts, Culture and Sports) policy.

Overall, Talent Visa and LTSSL Occupation work permit approval rates was high, particularly for Talent (Accredited Employers) applications ( 98 percent approval rate). Applications were processed very quickly compared to work permits issued through General work permit policy. On average. Talent (Accredited Employers) and LTSSL Occupation work permits were processed in 12 days.

Talent Visa and LTSSL Occupation work permits were issued to migrants from a broad range of nationalities, although the top five nationalities accounted for 73 percent of approvals. The UK was the largest source country for each of the three permit types, accounting for 48 percent of the combined total. Fifty-three percent of migrants employed through the Talent (Accredited Employers) policy were from the UK, as were 42 percent of LTSSL Occupation work permit holders. The other main source countries for the work to residence policies included South Africa ( 11 percent), Canada (6 percent), the USA (4 percent), and Germany (4 percent).

Work permit holders were employed in a broad range of occupations, although 80 percent overall worked in occupations classified as Legislators, administrators and managers, Professionals, or Technicians and associate professionals. A further 8 percent were classified as Trades 
workers. The high concentration in these occupational groups indicates the degree to which these policies have attracted skilled or talented migrants.

Talent Visa and LTSSL Occupation work permit holders were employed in regions throughout New Zealand. Those employed through the LTSSL Occupation policy had the greatest spread, with only 38 percent recording employment in Auckland. Sixtythree percent of Talent (Accredited Employers) work permit holders were employed in Auckland, reflecting the large proportion of accredited employers based there. The majority of those employed through the Talent (Arts, Culture and Sports) policy worked in New Zealand's three main population centres.

\section{Transitions to Permanent Residence}

Three residence policies complement the Talent Visa and LTSSL Occupation work permit policies. Talent Visa and LTSSL Occupation work permit holders may be granted residence through the associated residence policies after holding their work permit for 24 months. Applicants must have met the employment conditions of their work permit for the 24-month period. Talent (Accredited Employers) and LTSSL Occupation applicants must have full-time employment with a minimum base salary (calculated on the basis of a 40 hour week) of $\$ 45,000$.

Twenty-nine percent of Talent Visa and LTSSL Occupation work permit holders gained permanent residence between April 2002 and October 2005 (1,184 out of 4,064). The majority were approved through residence categories other than the intended residence from work routes, but nearly all were approved through skilled categories. Eighty-three percent gained permanent residence within 24 months of being issued their work to residence permit. Of those who gained permanent residence, 18 percent were approved through the associated residence from work policies and 78 percent were approved through other skilled categories, most notably the SMC. Most of the remaining four percent were approved through Partnership policy (Appendix Table 2).

Of the three work to residence policies, those who held a LTSSL Occupation work permit were most likely to gain residence within 24 months of being issued their work permit. They were also more likely to gain residence through the SMC (Appendix Table 3). LTSSL Occupation work permit holders are highly skilled, with qualifications and work experience that enables them to work in occupations on the LTSSL. These skilled workers are able to meet the policy requirements of the SMC, so it is not unexpected that many endeavour to obtain permanent residence through this policy route. ${ }^{6}$

There was little variation in the rates of transition to residence for work permit holders in the largest three occupational groups (Legislators, administrators and managers, Professionals, or Technicians and associate professionals). However, those classified as Professional had a greater tendency to convert to residence within 24 months of being issued their work permit.

Amongst the smaller occupational groups, Service and sales workers had the highest rate of transition to residence (58 percent), and were the most likely to gain residence after holding their work permit for 24 months or more. Plant and machinery operators were the least likely to convert to residence ( 8 percent).

Work permit holders from the five largest source countries had similar patterns of transition to residence, with the exception of Canada. Only 8 percent of Canadian work permit holders had converted to residence, compared to the UK ( 31 percent), South Africa ( 39 percent), the USA (24 percent), and Germany (25 percent). Further analysis showed that of the 253 Canadians issued a work permit, a high proportion ( 22 percent) had left New Zealand and had been out of the country for six months or more at the end of the analysis period.

In general, older work permit holders had a higher rate of transition to residence than those in the younger age ranges (excluding those under 20 and over 55, where numbers were small). Those aged 35 years or more had a higher than average rate of transition to residence (between 30 and 37 percent) compared to those under 35 (between 16 to 29 percent). Older work permit holders were also more likely to gain residence within 24 months of being issued their work permit.

Of the 1,184 people approved for residence, the average time taken from work permit approval to residence approval was 13 months. On average, LTSSL Occupation work permit holders who gained residence did so in less time than the Talent Visa work permit holders. The average time taken for LTSSL Occupation work permit holders ( 445 out of 1,184 ) to gain residence was 11 months. The comparable figure for Talent (Accredited Employers) work permit holders was 13 months, and for Talent (Arts, Culture and Sports) the average was 18 months.

Research has shown that some migrants are highly mobile, spending large amounts of time out of New Zealand, while others leave New Zealand permanently within a few years of being granted residence (Shorland, P. 2006). This analysis looked at the time spent in New Zealand after the initial Talent Visa or LTSSL Occupation work permit was issued (or the date of arrival in New Zealand for those issued a work visa offshore).

This research showed that eight percent of Talent Visa and LTSSL Occupation work permit holders left New Zealand without applying for residence and were absent for six months or more at the time of analysis. Of the eight percent, almost two-thirds left New Zealand within six months of gaining their work permit. Of the three policies, Talent (Accredited Employers) work permit holders were the most likely to stay in New Zealand. 


\section{Conclusions}

This research shows that the employer accreditation scheme and the associated Talent (Accredited Employers) work permit policy has worked well to enable accredited employers to recruit skilled and talented people from offshore. Accredited employers who responded to the online survey reported high rates of retention of the migrants they employed. An analysis of residence transition patterns showed that, compared to other work to residence work permit holders, Talent (Accredited Employers) work permit holders tended to remain on their work permit for longer before applying for residence.

The Talent (Accredited Employers) policy's salary threshold was seen by some stakeholders as a barrier to employing migrants, but this was shown to be occupation-specific. The majority of migrants employed through the Talent (Accredited Employers) policy had highly skilled occupations, and many earned well in excess of the salary threshold of $\$ 45.000$ per annum. The salary threshold was a greater barrier for employers recruiting in particular occupation groups, such as Trades workers, although these groups made up a relatively small proportion of work permit holders.

Talent Visa and LTSSL Occupation work permit holders are not required to meet a minimum standard of English. Similarly, there is no minimum standard of English for principal applicants who apply for residence through the Talent Visa and LTSSL residence categories. However, there was no evidence in this research to suggest that these policies had created an incentive for non-English speaking migrants to circumvent the English language requirements of other skilled residence policies. The four largest source countries for Talent Visa and LTSSL Occupation work permits were all English-speaking nations. and together accounted for 69 percent of approvals.

An analysis of the transition to permanent residence showed that many work to residence permit holders gained residence within 24 months of being issued their work permit - less time than intended by the work to residence policies. However, the majority of those who gained residence did so through a skilled residence category, even if it was not the route intended by work to residence policy.

There was a strong tendency for LTSSL Occupation work permit holders to gain residence through the SMC, often well within two years of being granted a work permit. LTSSL Occupation work permit holders are highly skilled, with the qualifications and work experience that are in high demand in New Zealand. To some extent, SMC policy competes with LTSSL residence policy because both policies aim to attract the same highly skilled migrants. SMC policy not only recognises the skills, qualifications, and experience of people with oceupations on the LTSSL, but offers bonus points for these attributes. Therefore, SMC policy can often provide a quicker route to residence for LTSSL Occupation work permit holders than would otherwise be the case through the LTSSL residence policy.

New Zealand's skilled immigration policies aim to attract qualified and skilled migrants who will contribute to New Zealand's economic transformation. This research will be used to inform the development of these policies to ensure that they continue to select migrants with the skills and talent to live and work successfully in New Zealand. The research will also help ensure that the policies remain responsive to New Zealand's needs in the future.

\section{Note}

I This paper is based on a full report, which is currently being prepared by the Department of Labour.

2 There is an age limit and minimum salary requirement at the time an applicant applies for permanent residence through the LTSSL Occupation residence category.

3 No salary threshold exists for Talent (Arts, Culture and Sports) applicants, although the applicant (or their partner or children) must not have applied for, or been granted, welfare assistance at any time since the grant of their work permit.

4 Stakeholders included accredited employers, immigration advisers (private sector), and immigration staff (Department of Labour).

5 In this context. 'category jumping' is when the work to residence permit holder gained residence through a category not intended by the policy, such as the SMC.

6 A person who has a job or offer of employment in an occupation on the Long Term Skill Shortage List meets the SMC requirements for skilled employment, and attracts bonus points for skilled employment in an area of absolute skills shortage.

\section{References}

Shorland, P., (2006). People on the Move: A Study of Migrant Movement Patterns to and fiom New Zealand. Wellington: Department of Labour.
Author
Paul Merwood
Research Analyst
Workforee Research and Evaluation
Department of Labour
P.O Box 3705
Wellington
Paul.Merwood $a$ dol.govt.nz 


\section{Appendix}

Table 2: Residence categories through which Talent Visa and LTSSL Occupation work permit holders gained residence approvalResidence approval category.

\begin{tabular}{|c|c|c|c|c|c|c|c|c|}
\hline & \multicolumn{6}{|c|}{ Work permit category } & \multirow{2}{*}{\multicolumn{2}{|c|}{ Total }} \\
\hline & \multicolumn{2}{|c|}{$\begin{array}{c}\text { Talent } \\
\text { (Accredited } \\
\text { Employers) }\end{array}$} & \multicolumn{2}{|c|}{ LTSSL } & \multicolumn{2}{|c|}{$\begin{array}{l}\text { Talent (Arts, } \\
\text { Culture and } \\
\text { Sports) }\end{array}$} & & \\
\hline & $\mathbf{n}$ & $\%$ & $\mathbf{n}$ & $\%$ & $\mathbf{n}$ & $\%$ & $\mathbf{n}$ & $\%$ \\
\hline Skilled Migrant Category & 451 & $65 \%$ & 376 & $84 \%$ & 12 & $27 \%$ & 839 & $71 \%$ \\
\hline Talent (Accredited Employers) & 181 & $26 \%$ & 0 & $0 \%$ & 0 & $0 \%$ & 182 & $15 \%$ \\
\hline 1995 General Skills Category & 39 & $6 \%$ & 44 & $10 \%$ & 0 & $0 \%$ & 83 & $7 \%$ \\
\hline Partnership & 14 & $2 \%$ & 6 & $1 \%$ & 4 & $9 \%$ & 24 & $2 \%$ \\
\hline LTSSL Occupation & 0 & $0 \%$ & 16 & $4 \%$ & 0 & $0 \%$ & 16 & $1 \%$ \\
\hline Talent - Sports & 0 & $0 \%$ & 0 & $0 \%$ & 13 & $30 \%$ & 13 & $1 \%$ \\
\hline Talent - Arts and Culture & 0 & $0 \%$ & 0 & $0 \%$ & 9 & $20 \%$ & 9 & $1 \%$ \\
\hline Ministerial direction & 5 & $1 \%$ & 1 & $0 \%$ & 2 & $5 \%$ & 8 & $1 \%$ \\
\hline Others & 5 & $1 \%$ & 2 & $0 \%$ & 4 & $9 \%$ & 10 & $1 \%$ \\
\hline Total & 695 & $100 \%$ & 445 & $100 \%$ & 44 & $100 \%$ & 1,184 & $100 \%$ \\
\hline
\end{tabular}

Table 3: Number of people converting to residence by Talent Visa and LTSSL Occupation work permit category.

\begin{tabular}{|c|c|c|c|c|c|c|c|}
\hline $\begin{array}{l}\text { Work } \\
\text { permit } \\
\text { criteria }\end{array}$ & $\begin{array}{c}\text { Total work } \\
\text { permits }\end{array}$ & $\begin{array}{c}\text { Total } \\
\text { residence } \\
\text { approvals }\end{array}$ & $\begin{array}{l}\% \text { gained } \\
\text { residence }\end{array}$ & $\begin{array}{c}\text { Time taken } \\
\text { to } \\
\text { transition } \\
\text { (months) }\end{array}$ & $\mathbf{n}$ & $\begin{array}{c}\% \text { of } \\
\text { residence } \\
\text { approvals }\end{array}$ & $\begin{array}{c}\% \text { of work } \\
\text { permits }\end{array}$ \\
\hline \multirow{2}{*}{$\begin{array}{l}\text { Talent } \\
\text { (Accredited } \\
\text { Employers) }\end{array}$} & \multirow[b]{2}{*}{2487} & \multirow[b]{2}{*}{695} & \multirow{2}{*}{$28 \%$} & $<24$ & 541 & $78 \%$ & $22 \%$ \\
\hline & & & & $24+$ & 154 & $22 \%$ & $6 \%$ \\
\hline \multirow{2}{*}{$\begin{array}{l}\text { LTSSL } \\
\text { Occupation }\end{array}$} & \multirow{2}{*}{1427} & \multirow{2}{*}{445} & \multirow{2}{*}{$31 \%$} & $<24$ & 417 & $94 \%$ & $29 \%$ \\
\hline & & & & $24+$ & 28 & $6 \%$ & $2 \%$ \\
\hline \multirow{2}{*}{$\begin{array}{l}\text { Talent (Arts, } \\
\text { Culture and } \\
\text { Sports }\end{array}$} & \multirow{2}{*}{150} & \multirow{2}{*}{44} & \multirow{2}{*}{$29 \%$} & $<24$ & 28 & $64 \%$ & $19 \%$ \\
\hline & & & & $24+$ & 16 & $36 \%$ & $11 \%$ \\
\hline \multirow{2}{*}{ Total } & \multirow{2}{*}{4,064} & \multirow{2}{*}{1,184} & \multirow{2}{*}{$29 \%$} & $<24$ & 986 & $83 \%$ & $24 \%$ \\
\hline & & & & $24+$ & 198 & $17 \%$ & $5 \%$ \\
\hline
\end{tabular}

